\title{
Calculating the Adjusted Monetary Base under Contemporaneous Reserve Requirements
}

\section{R. Alton Gilbert}

$\mathbf{T}$ HE adjusted monetary base is designed to be a single measure of all Federal Reserve actions, including changes in reserve requirements, that influence the money stock. It is equal to the source base plus a reserve adjustment magnitude (RAM) that accounts for changes in reserve requirements by the Federal Reserve."

The adoption of contemporaneous reserve requirements (CRR), which became effective in February of this year, did not affect the reserve requirement ratios applicable to any group of deposit liabilities. It did, however, alter the relationships between deposit liabilities and the periods over which depository institutions are required to hold reserves against them. ${ }^{2}$ This article describes how the adoption of CRR has modified the calculation of RAM and, hence, the adjusted monetary base.

A. Alton Gibert is a research officer at the Federal Reserve Bank of St. Louis. John G. Schulte provided research assistance.

'The following articles describe and explain the adjusted monetary base in greater detail: Gibert (1980), Tatom (1980) and Gibert (1983).

${ }^{2}$ For a general description of the new system of contemporaneots reserve requirements, see Gilbert and Trebing (1982).

\section{THE CALCULATION OF RAM AND THE ADJUSTED MONETARY BASE}

RAM is calculated as the difference between the reserves that would have been required (given current deposit liabilities) if the base period's reserve requirements were in effect and the reserves that are actually required (given current requirements). Adding RAM to the source base produces an adjusted monetary base series that shows what the source base would have had to be, given the deposit liabilities for each period, if the reserve requirement ratios had always been those of the base period. ${ }^{3}$ Thus, this procedure converts reserve requirement changes into equivalent changes in the source base, holding the reserve requirements constant.

The base period for calculating RAM is January 1976 through August 1980. Base period reserve requirements are the average reserve requirements over that period for two categories of deposit liabilities: check-

\footnotetext{
${ }^{3}$ The source base equals the reserve balances of depository institutions with Federal Reserve Banks, which excludes their required clearing balances, ptus total currency in circulation, whether held by depository institutions or the public. It is derived from the combined balance sheets of the Federal Reserve Banks and the U.S. Treasury.
} 
able deposits and total time and savings deposits. For member banks, the average reserve requirement was 12.664 percent on checkable deposits and 3.1964 percent on total time and savings deposits. ${ }^{4}$ For nonmember institutions, base period reserve requirements were zero, since they were not subject to reserve requirements of the Federal Reserve in the base period. Thus, RAM is calculated as the current checkable deposits of member banks multiplied by 0.12664 , plus the current total time and savings deposits of member banks multiplied by 0.031964 , minus the current required reserves of all depository institutions.

\section{CALCULATION OF RAM UNDER THE PRIOR SYSTEM OF LAGGED RESERVE REQUIREMENTS}

The specific data on deposit liabilities and required reserves used to calculate RAM necessarily reflect the system of reserve accounting in effect. Under lagged reserve requirements (LRR), the average reserves of a depository institution over the seven-day reserve maintenance period ending each Wednesday must equal or exceed its required reserves. The required reserves for a depository institution in each maintenance week were based on its average deposit liabilities over the seven-day period ending 14 days before the end of the current maintenance week. Thus, in calculating RAM under $L, R R$, data on the required reserves of depository institutions for each maintenance week were matched with the deposit liabilities of member banks of two weeks earlier.

\section{THE CALGULATION OF RAM UNDER CRP}

Under $\mathrm{CRR}$, the reserve maintenance periods, during which average reserves must equal or exceed required reserves, have been lengthened to two-week periods that end every other Wednesday. Required reserves on checkable deposits for the current two-week maintenance period are based on daily average checkable deposits for the 14-day period ending two days before the end of the current maintenance period. Required reserves on time and savings deposits are based on daily average deposits over a 14-day period ending 30 days before the end of the current maintenance period. ${ }^{5}$ Table 1 presents the timing of reserve accounting for maintenance periods in 1984.

\footnotetext{
${ }^{4}$ Gilbert (1980).

${ }^{5}$ The timing of reserve accounting for valutt cash is also altered under CRR. Under the previous LRR system, the average vault cash held
}

\section{Calculating RAM: An Example}

The calculation of RAM must be adjusted to the new timing of reserve accounting under CRR. The new procedure for calculating RAM is illustrated for the first maintenance period under CRR: February 2 through February 15, 1984. Required reserves for that period are based on daily average checkable deposits over the period January 31 through February 13, and daily average time and savings deposits from January 3 through January 16. For this maintenance period, RAM is calcum lated as the average of total time and savings deposits of member banks over January 3-16 multiplied by 0.031964 , plus average checkable deposits of member banks over January 31-February 13 multiplied by 0.12664 , minus the required reserves of all depository institutions for the period February $2-15$. In calculating RAM for the next maintenance period, February 16 through February 29, observations for each category of deposit liabilities and required reserves apply to periods brought forward 14 days.

\section{Calculating a Weekly Adjusted Monetary Base with a Biweekly RAM}

Given the timing of reserve accounting under CRR, RAM is calculated for two-week periods ending every other Wednesday. This Bank's adjusted monetary base will still be published on a weekly basis for seven days ending each Wednesday. The measurement of the source base is not affected by the change to CRR, since it is derived from the balance sheets of Federal Reserve Banks and the U.S. Treasury. The adjusted monetary base is calculated for each week by adding the value of RAM that covers that week to the value of the source base. Because of the timing of reserve accounting under CRR, each value for RAM is used in calculating two weekly observations for the adjusted monetary base.

\section{THE MOST RECENT VALUES OF PAM MUST BE ESTMMATED}

The change from LRR to CRR changes the avalability of data necessary to calculate RAM. Previously, under LRR, data on required reserves and the lagged values of

\footnotetext{
by a depository institution over the seven-day period ending 14 days before the end of the current maintenance period counted as part of reserves in the current maintenance period. Under CRR, the average vault cash held over a 14-day period ending 30 days before the end of the current maintenance period counts as reserves in the current maintenance period. The timing of reserve accounting for vault cash is not discussed in the text because it does not influence calculation of the adjusted monetary base.
} 
Table 1

\section{Reserve Pertods}

Computation and Maintenance Dates Under Contemporaneous Reserve Requirements (weekly reporters)

\begin{tabular}{|c|c|c|c|}
\hline \multirow{2}{*}{ 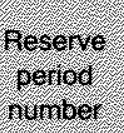 } & \multirow[b]{2}{*}{ Mantenarice perod } & \multicolumn{2}{|c|}{ computation perod } \\
\hline & & Nont ramsaction accounts & Transaction acrourts \\
\hline 1 & $2 \cdot 284=211584$ & 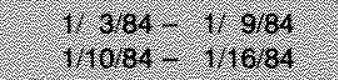 & 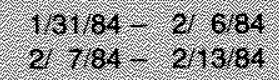 \\
\hline 2 & $2,16,64: 229.84$ & 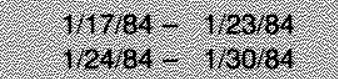 & 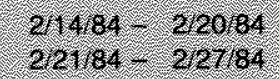 \\
\hline 3 & $3.184,314,84$ & 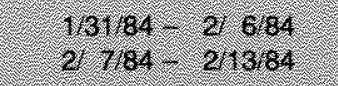 & 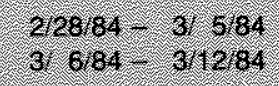 \\
\hline 4 & 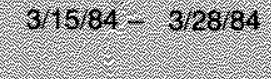 & 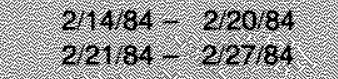 & 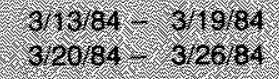 \\
\hline 5 & 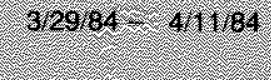 & $328.84=5854$ & 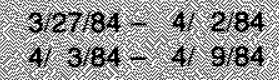 \\
\hline 6 & 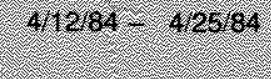 & $31364=31964$ & 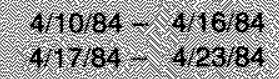 \\
\hline te & $-42694,57.984$ & 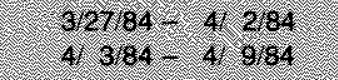 & $\begin{array}{l}4,484=460864 \\
5.164=57\end{array}$ \\
\hline 8 & $5.10 \% 84=5: 23784$ & 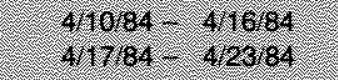 & $5.8794=514,04$ \\
\hline 9 & $5,24,84=64,644$ & $5.64 .84 \div=5.3064$ & $522094=5.504$ \\
\hline 10 & $607,784=6.20764$ & $5.6184=5,1484$ & 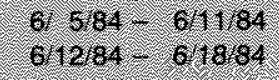 \\
\hline 11 & 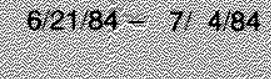 & 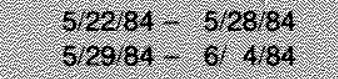 & $6,1984-6,25,84$ \\
\hline 12 & $7,5.84 .517804$ & $6.584=6.1784$ & $7,3.84=7.984$ \\
\hline 16 & $71984-619184$ & $\begin{array}{l}6,19,84 \\
6.26,84\end{array}$ & $717.84,7.23064$ \\
\hline 14 & $81294=58,1504$ & 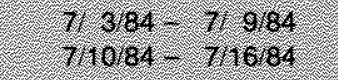 & 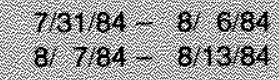 \\
\hline 15 & $81664=82986$ & $\begin{array}{l}71784=7 \\
724,84\end{array}$ & $81404-8.2084$ \\
\hline 16 & $8.150184=9,1284$ & 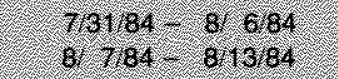 & 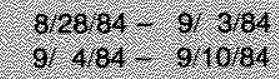 \\
\hline 17 & $91,0104+926064$ & 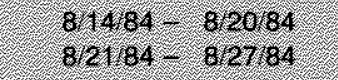 & $911864-917784$ \\
\hline 16 & $92764 \cdot 101084$ & 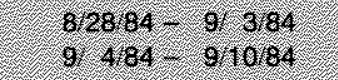 & $\begin{array}{l}9,2584=10 \\
10,2584\end{array}$ \\
\hline 19 & $1001194-102486$ & $9.11184=9.1784$ & $\begin{array}{l}101.964-1001584 \\
101,684=102284\end{array}$ \\
\hline 20 & $10025894=107.764$ & 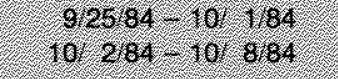 & $\begin{array}{l}1023564 \\
10 / 3064\end{array}-10,29: 84$ \\
\hline 21 & $11,0,84=11,21,64$ & 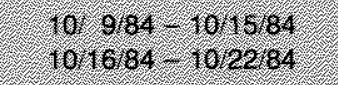 & $\begin{array}{l}11,684-1117284 \\
11,1384\end{array}$ \\
\hline 22 & $112284-12.5184$ & $10,2364.1029684$ & 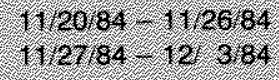 \\
\hline 23 & $12.6864,12,19894$ & $\begin{array}{l}11,6.84 \\
11,18.84\end{array}$ & $\begin{array}{l}12.484 \\
1211.84\end{array}$ \\
\hline 24 & $12.20684=10.2 .85$ & $\begin{array}{l}11,2084 \\
1,2784\end{array}$ & $12418.84,1234.84$ \\
\hline
\end{tabular}


deposit liabilities used in calculating RAM were available before the end of a maintenance period. Thus, RAM could be calculated before data were available on the source base. Under CRR, however, it will not be possible to calculate RAM until more than a week after the end of each maintenance period.

The difference in the timing of the data necessary to calculate RAM under LRR and CRR, and the problem CRR creates for calculating a weekly adjusted monetary base, are illustrated for the last maintenance period under LRR and the first two maintenance periods under CRR. Required reserves for the week ending February 1 were based on average deposit lia bilities for the week ending January 18 . The data on deposit liabilities and required reserves necessary for calculating RAM for the week ending February 1 were available by February 1. Because the source base for the seven days ending February 1 was available by February 3 , the exact adjusted monetary base for the week ending February 1 was published in this Bank's U.S. Financial Data on February $3,1984$.

The data necessary for calculating the value of RAM for the next maintenance period, the 14 days ending February 15, were available on February 23 . If publication of the adjusted monetary base was delayed until all data necessary for calculating RAM were available, the adjusted monetary base for the weeks ending February 8 and 15 would not be published until February 23 . Such delays can be avoided only by estimating RAM for the most recent maintenance period. This is done for the adjusted monetary base series published in this Bank's U.S. Financial Data release, with preliminary data published for the most recent one or two weeks (see table 2 ).

If there is no change in reserve requirements, the estimate of RAM used to obtain the preliminary weekly adjusted monetary base is the value of RAM for the most recent maintenance period. If a change in reserve requirements becomes effective during the current maintenance period, however, the estimated RAM for this period equals its lagged value plus an estimate of the effect of the change in reserve requirements on required reserves.

A change in reserve requirements became effective in the maintenance period covering the two weeks ending February 15, the last phased reduction in reserve requirements of member banks specified in the Monetary Control Act of 1980. The prior phased reductions in member bank reserve requirements reduced total required reserves by about $\$ 2$ billion (see figure 1 ).

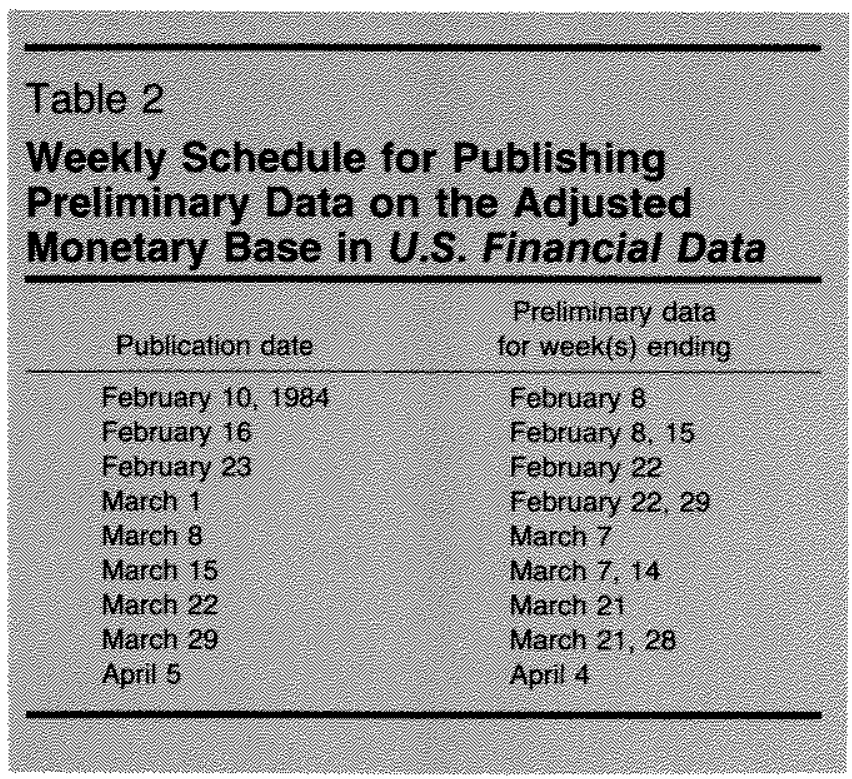

Thus, the estimated value of RAM used in calculating preliminary values of the adjusted monetary base for the weeks ending February 8 and February 15 was the value of RAM calculated for the week ending February 1 plus $\$ 2$ billion. A preliminary value of the adjusted monetary base for the week ending February 8 , published on February 10, was calculated as the source base for the week ending February 8 plus that estimated value of RAM.

Note that the deposit data for the week ending January 18 were used to derive this value of RAM. This value is subject to further revisions due to revisions of both the deposit data for the week ending January 18 and the required reserves for the week ending February 1. The preliminary number for the adjusted monetary base for the following week, the seven days ending February 15, which was published on February 16, equals the source base for the week ending February 15 plus the estimated value of RAM.

By February 23, the data on checkable deposits and required reserves were available to calculate RAM for the two weeks ending February 15. At that time, the preliminary adjusted monetary base data for the weeks ending February 8 and 15 were revised to incorporate the new value for RAM. Moreover, this latest value for RAM was used in calculating the preliminary value of the adjusted monetary base for the week ending February 22 (published on February 23 ), and the preliminary value for the week ending February 29 (published on March 1). When using this approach to calculate the weekly adjusted monetary base series, either one or two of the most recent weekly observations are preliminary. RAM for the current and prior weeks remains 
Chan F

Two-Week Averages of RAM

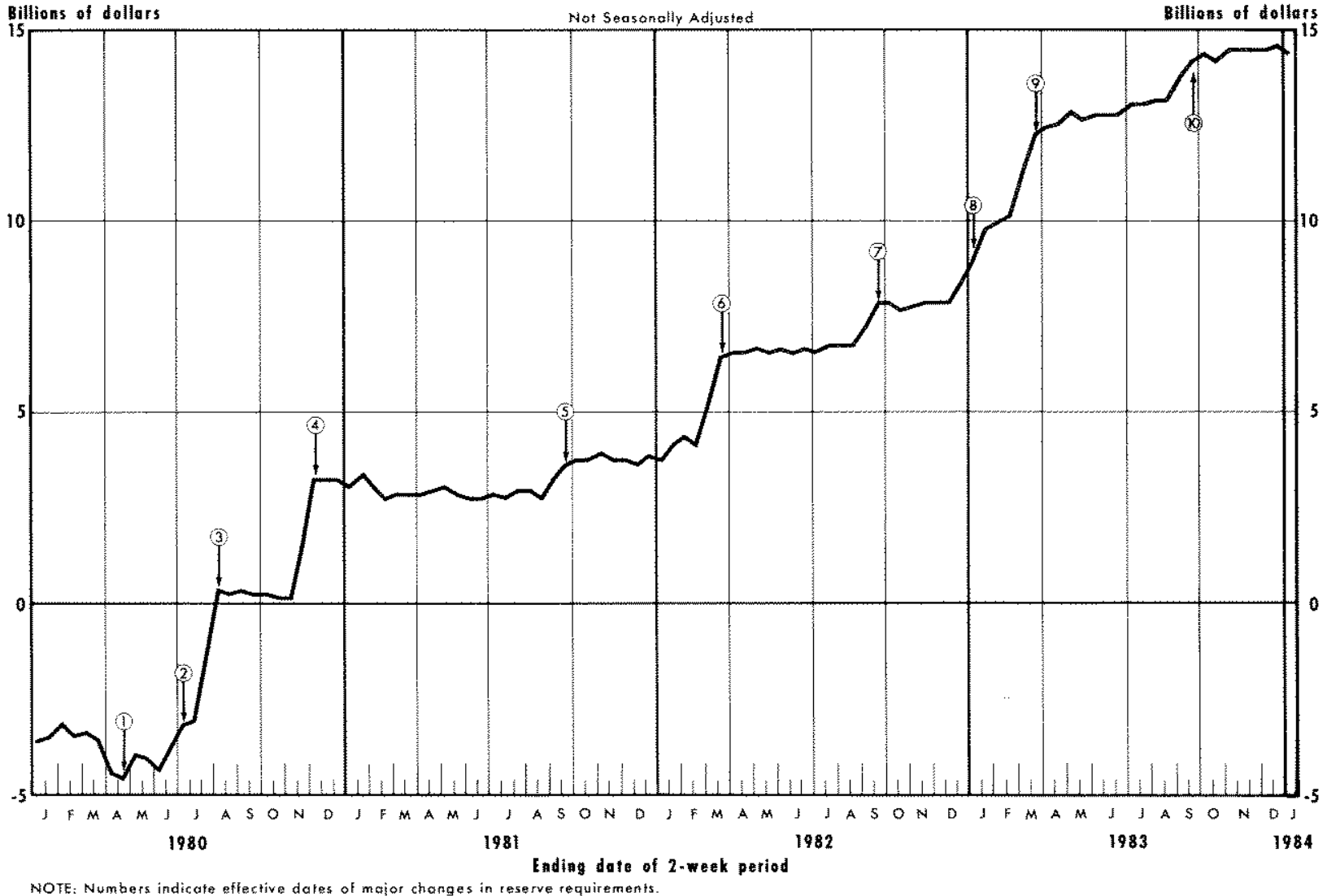

1. The 8 percentage poin marginal reserve requirement was raised to 10 percent, In addition, the base upon which the marginal reserve requirement is calculated was reduced. This action increased required reserves about $\$ 1.7$ billion.

2. The marginal reserve requirement was reduced from 10 to 5 percentage points and the base upon which the marginal reserve requirement is calculated was raised. This action reduced required reserves about $\$ 980$ miltion.

3. The 5 percent marginal reserve requirement on managed liabilities and the 2 percent supplementary reserve requirement against large time deposits were removed. These actions reduced required reserves about $\$ 3.2$ billion.

4. Required reserves of member banks and Edge Act corporations were reduced about $\$ 4.3$ billion and required reserves of other depository institutions were increased about $\$ 1.4$ billion due to the implementation of the Monetary Control Act of 1980 .

5. In conjunction with the transitional phase-in program under the Monetary Control Act, required reserves of member banks were reduced $\$ 2.0$ billion, and required reserves of other depository institutions were increased $\$ 0.9$ billion.

6. In conjunction with the transitional phase-in program under the Monetary Control Act, required reserves of member banks decreased by $\$ 20$ billion.

7. In conjunction with the transitional phase-in program under the Monetary Control Act, required reserves of member banks were reduced $\$ 2.1$ billion, and required reserves of other depository institutions were increased $\$ 0.9$ billion.

8. In accordance with provisions of the Depository Institutions Act of 1982 that exempted the first $\$ 2.1$ million of reservable liabilities at all depository institutions from reserve requirements, required reserves were reduced by an estimated $\$ 800$ miltion.

9. In conjunction with the transitional phase-in program under the Monetary Control Act, required reserves of member banks were reduced by approximately $\$ 1.9$ billion. Also, the reserves released by the growth of money market deposit accounts (available after midDecember 1982) produced an upward dritt in RAM during 1983, especially during the first half of the year.

10. In coniunction with the transitional phase-in program under the Monetary Control Act, required reserves of member banks were reduced $\$ 2.0$ billion, and required reserves of other depository institutions were increased $\$ 0.9$ billion. 
subject to revisions due to revisions in the data on deposit liabilities and required reserves.

\section{ERRORS IN ESTIMATING RAM ARE LIKELY TO BE SMALL.}

Errors in estimating RAM with its lagged value generally will be small relative to the size of the adjusted monetary base. The size of the errors using this approach are simulated for the period from 1980 through early 1984, using the average RAM calculated for each two-week period over these four years. For periods when no changes in reserve requirements occurred, the eгror in using the value for the prior twoweek period to estimate RAM for the current period was less than $\$ 100$ million in half of the periods, and less than or equal to $\$ 200$ million in about 84 percent of the periods.

As chart 1 indicates, large changes in RAM typically have occurred only when there have been major changes in reserve requirements. Changes in RAM, other than those resulting from the 10 major changes in reserve requirements identified in chart 1 , have been relatively small.

Errors in estimating the effects of changes in reserve requirements should not generally be large. The Federal Reserve is generally able to estimate the effects of a change in reserve requirements on required reserves very accurately. Furthermore, most changes in reserve requirements have applied to time and savings deposits. ${ }^{6}$ Since under CRR, the time and savings deposits subject to reserve requirements in a reserve maintenance period are lagged four weeks, data should be available to indicate the effects of those changes on required reserves when the preliminary data on the adjusted monetary base are published.

To illustrate the timing, suppose that reserve requirement ratios on time and savings deposits were raised, effective in the maintenance period covering the two weeks ending February 29. Required reserves for that maintenance period are based on average time and savings deposits over the two weeks ending January 30. The first weekly observation of the adjusted monetary base affected by that change in reserve re-

\footnotetext{
${ }^{6}$ Changes in reserve requirements since November 1980 are dictated by the Monetary Control Act of 1980 and the Depository Institutions Act of 1982; they apply to both checkable deposits and to time and savings deposits. From 1960 until November 1980, the Board of Governors changed reserve requirements 35 times. Only 11 of those changes involved demand deposits.
}

quirements, covering the week ending February 22, would be published on February 23.

\section{THE PUBLICATION OF ADJUSTED RESERVES UNDER CRR}

Adjusted reserves will not be published weekly under CRR. Adjusted reserves are calculated by subtracting seasonally adjusted currency in the hands of the public from the adjusted monetary base, seasonally adjusted. Until February 1984, weekly observations for currency in the hands of the public covered sevenday periods ending each Wednesday, the same periods that applied to weekly observations of the adjusted monetary base. Weekly currency data now cover the seven days ending each Monday, matching the timing of weekly average checkable deposits under CRR. With this change in timing, it would be inappropriate to subtract weekly average currency from weekly average adjusted monetary base to obtain a weekly adjusted reserves series; the periods for currency and the adjusted monetary base do not match up. The change described above in the timing of data on currency in the hands of the public probably has little effect on data for monthly average currency. This Bank, therefore, will continue to publish adjusted reserves on a monthly average basis.

\section{GONCLUSIONS}

The timing of data used in calculating the adjusted monetary base has been changed to reflect the timing of reserve accounting under the new system of contemporaneous reserve requirements, Observations for the adjusted monetary base for the most recent one or two weeks will be preliminary, because the most recent values of the reserve adjustment magnitude will be estimated. The adjusted reserves series will no longer be published on a weekly basis, due to a change in the days covered by weekly average data on currency in the hands of the public. This Bank will continue to publish the adjusted reserves series on a monthly average basis.

\section{REFERENCES}

Gilbert, R. Alton. "Revision of the St. Louss Federal Reserve Adjusted Monetary Base," this Review (December 1980), pp. 3-10.

"Two Measures of Reserves: Why Are They Different?" this Review (June/July 1983), pp. 16-25.

Gilbert, R. Alton, and Michael E. Trebing. "The New System of Contemporaneous Reserve Requirements," this Review (Decem. ber 1982), pp. 3-7.

Tatom, John A. "Issues in Measuring an Adjusted Monetary Base," this Review (December 1980), pp. 11-29. 